THE FUTURE OF THE US-REPUBLIC OF KOREA MILITARY RELATIONSHIP 


\section{The Future of the US-Republic of Korea Military Relationship}

Kim Jung-Ik US Policy Division

Ministry of National Defense

Republic of Korea Army

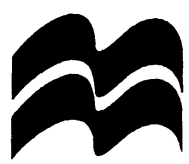


First published in Great Britain 1996 by

MACMILLAN PRESS LTD

Houndnills, Basingstoke, Hampshire RG21 6XS

and London

Companies and representatives

throughout the world

A catalogue record for this book is available

from the British Library.

ISBN 978-1-349-13912-5 ISBN 978-1-349-13910-1 (eBook)

DOI 10.1007/978-1-349-13910-1

First published in the United States of America 1996 by

ST. MAR'TIN'S PRESS, INC.,

Scholarly and Reference Division,

175 Fifth Avenue,

New York, N.Y. 10010

ISBN 978-0-312-12967-5

Library of Congress Cataloging-in-Publication Data

Kim, Jung-Ik.

The future of the US-Republic of Korea military relationship / Kim

Jung-Ik.

p. $\mathrm{cm}$.

Includes bibliographical references and index.

ISBN 978-0-312-12967-5 (cloth)

1. United States-Military relations-Korea (South) 2. Korea

(South)-Military relations-United States. I. Title.

E183.8.K7K55 1996

$327.7305195-\mathrm{dc} 20$

95-48386

CIP

(c) Kim Jung-Ik 1996

Softcover reprint of the hardcover 1st edition 1996

All rights reserved. No reproduction, copy or transmission of this publication may be made without written permission.

No paragraph of this publication may be reproduced, copied or transmitted save with written permission or in accordance with the provisions of the Copyright, Designs and Patents Act 1988, or under the terms of any licence permitting limited copying issued by the Copyright Licensing Agency, 90 Tottenham Court Road, London WIP 9HE.

Any person who does any unauthorised act in relation to this publication may be liable to criminal prosecution and civil claims for damages.

$\begin{array}{llllllllll}10 & 9 & 8 & 7 & 6 & 5 & 4 & 3 & 2 & 1\end{array}$

$\begin{array}{llllllllll}05 & 04 & 03 & 02 & 01 & 00 & 99 & 98 & 97 & 96\end{array}$ 
To the Army of the Republic of Korea 


\section{Contents}

List of Tables

List of Figures and Map

Acknowledgements

Summary

$\mathrm{x}$

1 Introduction 1

2 The United States-Republic of Korea Strategic

Relationship, 1945-93

How the Relationship Originated

The Liberation of Korea

The Korean War

How the US-ROK Relationship Evolved

Inevitable Alliance

After the Nixon Doctrine $\quad 22$

Strengthened Partnership $\quad 25$

The Position in $1993 \quad 27$

Conclusion $\quad 29$

3 The United States-Republic of Korea Military

Relationship, 1945-93

The Military of the Republic of Korea

Total Dependence: Before, During, After the Korean War 31

Self-Awakening: After the Vietnam War 35

Partial Dependence: Reduction of US Military Assistance and the Force Improvement Program 38

Mission for the Future: Toward Self-Reliance $\quad 47$

US Forces in Korea

After the Korean War $\quad 48$

After the Nixon Doctrine $\quad 49$

Reinforcement of Subordinate Units 51

US Air Force in Korea $\quad 52$

Nuclear Weapons $\quad 54$ 
Combined Command Structure and Exercises

Combined command structure $\quad 54$

Combined exercises $\quad 57$

Burden-Sharing $\quad 59$

Conclusion $\quad 65$

4 The Changing Security Environment 68

The End of the Cold War: The Change in Moscow's Asian Policy Moscow-Beijing Relations $\quad 70$

Approach to Asian Economies $\quad 72$

The Possibility of Russia Becoming a Truly

Asian Power $\quad 74$

The Consequences of Changes in Russia for the Security of

$\begin{array}{ll}\text { South Korea } & 78\end{array}$

The Death of Kim Il-Sung and the Nuclear Issue 79

Continuing Intraregional Defence Efforts

$\begin{array}{lr}\text { Russia } & 82\end{array}$

Japan $\quad 86$

China $\quad 91$

North Korea $\quad 95$

$\begin{array}{ll}\text { Conclusion } & 97\end{array}$

5 Possible Evolution of the US-ROK Strategic Relationship 101

US Objectives in Asia 101

Mcasures Taken to Achieve US Asian Objectives 104

Implications of the New US Asian Policy 107

The Strategic Importance of South Korea 109

The Attitude of the South Korean Government 114

Possible Evolution of the Strategic Relationship 119

6 Possible Evolution of the US-ROK Military Relationship 128

The Future of US Military Strategy in Asia 128

Debates about the Future of the US Forces in Korea 134

The Response of the US Government 143

$\begin{array}{ll}\text { Conclusion } & 147\end{array}$

7 The Security of South Korea and the US-ROK Military Relationship

The Future of the US-ROK Military Relationship:

The Nuclear Development 
The Future of the US-ROK Military Relationship:

The Force Withdrawal Plan

8 Options for the Security of South Korea 160

Option One: Greater Self-Reliance

South Korean Defence Industry 161

To Achieve Self-Reliance 166

Option Two: Holding the US Military

$\begin{array}{ll}\text { The Importance of the USFK } & 169\end{array}$

How to Hold US Forces: Greater Burden-Sharing? 173

Increasing Japanese and Chinese Military Power 177

$\begin{array}{ll}\text { Conclusion } & 178\end{array}$

Notes $\quad 183$

Bibliography $\quad 202$

Index 209 


\section{List of Tables}

3.1 US Assistance to the ROK Military Budget 35

3.2 US Military Assistance to South Korea during MOD 40

3.3 Trade in Major Conventional Weapons of South Korea, 1971-86 41

3.4 Comparison of Military Forces of South Korea 1977, $1981 \quad 43$

3.5 Comparison of North-South Korean Military Forces, July 1989

3.6 US Military Strength in Korea $\quad 51$

3.7 The Number of US Aircraft in Korea 53

3.8 Cost of US Forces in Korea 61

3.9 ROK Financial Support for US Troops in $1988 \quad 62$

3.10 The ROK's Contribution to the USFK 62

3.11 Cost of US Forces in ROK and Japan in 1988

3.12 The Cost of Demobilizing US Forces in Korea 64

4.1 Asian Countries Trade Dependence on Major Markets 75

4.2 Soviet Nuclear Forces in Far East Theatre 83

4.3 Attack Submarines 83

4.4 Surface Combatants $\quad 84$

4.5 Japanese Military Build-Up 1978-89 88

4.6 Scale of Procurement for FY 1991-95 90

5.1 South Korean View of North-South Military Balance 117

5.2 Comparison of Policy between the United States and
South Korea

6.1 Conventional Conflict Scenarios 130

6.2 Iraq Equivalent of North Korea 136

6.3 Proposals about the Future of the US Forces in Korea 141

6.4 Reasons for the Withdrawal of the US Ground Forces

6.5 Reasons for Stationing the US Ground Forces in Korea 142

6.6 Phased Troop Reductions 145

8.1 North-South Numerical Balance, 1991 


\section{List of Figures}

3.1 Command and Control of the CFC 56

6.1 The Base Force Supports the Strategy 132

MAP

3.1 The Location of US Forces in Korea, 1986 


\section{Acknowledgements}

I would like to express special thanks to the ROK Army for providing this invaluable opportunity for study at the Centre for Defence Studies at Aberdeen University and financial support during my studies.

On completing this dissertation, I wish to express my feelings of gratitude and appreciation to my supervisor, Mr David Greenwood, for his valuable advice and comments on the subject. His immense knowledge and experience have been essential to me in improving this dissertation, both stylistically and substantively.

I thank my colleague, Miss Gillian Wylie, for her constant reading of my chapters and acting as an informant with a native speaker's intuition.

I am happy to acknowledge my indebtedness to my family: my parents and in-laws for their consistent love and praying throughout these years. I have been fortunate in having my wife's unfailing encouragement and my dearest six-year-old son's incredible patience. 


\section{Summary}

Since the end of the Second World War the security of South Korea has been dependent on the actions of the United States, whose chief interest was to block communist expansion in the free world. Throughout the Cold War the US was interested in defending South Korea from communist attack and by doing so to maintain stability in Northeast Asia. The close military relationship between the two countries was a direct result of this strategic consideration.

With the end of the Cold War, the strategic and military commitments of the United States have changed and thanks to the economic downturn, the United States has tried to cut defence expenditure. Without an apparent enemy, the US post-Cold War strategy now focuses on preventing regional conflicts and promoting human rights. As expected, the number of soldiers in forward bases throughout the world, including South Korea, has been reduced.

But for North Korean nuclear development, the force withdrawal programme declared by the Bush administration would have been executed as scheduled, forcing South Korea to take a leading role in defending the country by the end of this century. A conventional war in the Korean Peninsula will not seriously affect the strategic interests of the United States in Asia as long as the security of Japan is not threatened. The South Korean military may be able to stall an invasion by North Korea for some time until the international community responds. The United States no longer needs to sacrifice American lives by being directly involved in a military conflict in Korea. This being so, South Korea will be forced to take a leading role and allow the majority of US forces in Korea to leave.

The strategic considerations of the United States have been disturbed by the alleged North Korcan nuclear development and the North's refusal to open suspected sites to the UN inspection team. Worried about nuclear proliferation, the prevention of which is one of the US post-Cold War objectives, the United States has been trying to stop the development and to put the sites under IAEA supervision by making direct contact with North Korea. Although the force withdrawal programme has been suspended to give the impression to North Korea of US determination, concessions like the cancellation of the Team Spirit joint military exercise have also been offered. 
Like the United States, South Korea has been preoccupied with stopping North Korean nuclear development, but this has proved to be beyond its reach. Therefore, what is the most practical way to ensure the security of South Korca? Considering the behaviour of the North over the years and the reports on the progress of nuclear weapons development, it would be dangerous to believe that North Korea does not have nuclear weapons.

South Korea should consider the North Korean nuclear threat as well as the possibility of a conventional attack. In the new era when the United States is not likely to intervene automatically in a Korean conflict, the reliance on the US forces for security should be reconsidered. Due to the withdrawal of tactical nuclear weapons from Korea, which greatly affect the forward defence strategy of South Korea, it has already been rendered short of the fire-power necessary to stop a North Korean conventional attack, which would be characterized by deep penetration and successive strikes. South Korea should consider increasing fire-power to stop such a conventional attack and at the same time find a way to deter the North Korean nuclear threat. 